\title{
EFEKTIVITAS MULTIMEDIA DALAM BIOFILTER PADA PENGOLAHAN AIR LIMBAH RUMAH TANGGA \\ (The effectiveness of multimedia in biofilters on grey water treatments)
}

\author{
Muhamad Yusup Hidayat ${ }^{1}$, Ridwan Fauzi ${ }^{1}$, Alfrida Esther Suoth ${ }^{1}$ \\ ${ }^{1}$ Pusat Penelitian dan Pengembangan Kualitas dan Laboratorium Lingkungan \\ Kawasan Puspiptek Gedung 210, Tangerang Selatan, 15314, Indonesia \\ E-mail: yusup.fairuz@gmail.com
}

Diterima: 14 Agustus 2019; Direvisi : 9 Oktober 2019; Disetujui : 11 November 2019

\begin{abstract}
Population growth in major cities in Indonesia has implications to the increase of clean water consumption. The highest demand of clean water is in fulfilling household needs. The use of clean water for household needs does not follow the efficiency principle. So that in fulfilling the water needs, it is necessary to use other sources, one of which is grey water. This study aims to determine the effectiveness of multimedia contacts by adding wood shavings as biofilter material in treating grey water. The applied method in this research is quantitative with a qualitative descriptive approach, by conducting experiments using wood shavings as a material for biofilter. This research was carried out in the residential of Villa Bintang Mas, South Tangerang City in October 2018. The results showed that the usage of biofilter materials with the addition of wood shavings was effective in removing the pollutant of the grey water. It is indicated by the level of biofilter efficiency in reducing pollutant concentrations ranging from $40.6 \%$ (BOD parameters) to $100 \%$ (Coliform parameters). Nevertheless, Coliform parameters still do not meet the standard quality, therefore, there is a need for additional disinfectants to reduce Coliform levels.
\end{abstract}

Keywords: grey water; biofilter; wood shavings; multimedia

\begin{abstract}
ABSTRAK
Pertumbuhan penduduk pada kota-kota besar di Indonesia berimplikasi pada peningkatan konsumsi air bersih. Konsumsi air bersih terbesar salah satunya dalam pemenuhan kebutuhan domestik rumah tangga. Penggunaan air bersih untuk kebutuhan domestik saat ini masih belum mengikuti kaidah efisiensi dalam penggunaannya. Oleh karena itu, dalam pemenuhan kebutuhan air tersebut perlu dilakukan pemanfaatan sumber lainnya, salah satunya adalah air sisa limbah domestik rumah tangga (grey water). Penelitian ini bertujuan untuk mengetahui efektivitas kontak multimedia dengan penambahan serutan kayu sebagai media biofilter dalam mengolah air limbah domestik rumah tangga (grey water). Penelitian ini dilakukan melalui percobaan penggunaan multimedia dengan penambahan serutan kayu sebagai media kontak biofilter. Penelitian ini dilaksanakan di perumahan Villa Bintang Mas, Kota Tangerang Selatan pada bulan Oktober 2018. Hasil penelitian menunjukkan bahwa
\end{abstract}


penggunaan multimedia biofilter dengan penambahan serutan kayu efektif dalam penyisihan pencemar pada air limbah domestik rumah tangga. Hal tersebut ditunjukkan dengan tingkat efisiensi alat dalam menurunkan konsentrasi pencemar berkisar antara 40,6\% (parameter BOD) sampai dengan 100\% (parameter Coliform). Meskipun demikian, parameter Coliform masih belum memenuhi standar baku mutu, sehingga perlu penambahan disinfektan untuk menurunkan kadar Coliform.

\section{Kata kunci: limbah domestik; biofilter; serutan kayu; multimedia}

\section{PENDAHULUAN}

Badan Perencanaan Pembangunan Nasional memproyeksikan laju pertumbuhan penduduk di Indonesia masih terus meningkat yaitu dari 238,5 juta pada tahun 2010 menjadi 305,6 juta pada tahun 2035 (Badan Pusat Statistik Indonesia, 2013). Pertumbuhan jumlah penduduk di wilayah perkotaan telah berdampak langsung terhadap kebutuhan akan jumlah perumahan yang ada. Data Real Estate Indonesia (REI) menunjukkan bahwa kebutuhan akan perumahan sebesar 11,4 juta dan akan terus bertambah tiap tahunnya (Bayu, 2018).

Pesatnya laju pertumbuhan perumahan yang ada saat ini ditambah dengan persaingan harga jual, terutama pada perumahan-perumahan menengah ke bawah mengakibatkan sebagian pengembang hanya menerapkan sistem sanitasi lingkungan yang sederhana. Pembuangan limbah domestik rumah tangga (greywater) yang ada seringkali masih dialirkan melalui selokan-selokan sederhana yang langsung bermuara ke dalam aliran sungai, tanpa terlebih dahulu melalui proses perlakuan (treatment). Kondisi ini apabila dibiarkan terus berlalu dapat menyebabkan permasalalah baru, terutama kenaikan beban pencemar sungai dari sumber rumah tangga (point source).
Permasalahan tentang pengelolaan air limbah rumah tangga tersebut banyak juga ditemukan di beberapa negara baik negara maju maupun negara yang dalam tahap berkembang (Jing et al., 2015).

Salah satu langkah yang dapat diterapkan untuk menangani permasalahan limbah domestik rumah tangga (grey water) yaitu dengan memanfaatkan biofilter. Prinsip kerja biofilter yaitu dengan cara mendegradasi limbah cair rumah tangga yang ada dengan media kontak (biofilm) (Maeng, Choi, \& Dockko, 2015; Wardiha \& Prihandono, 2015). Pada saat operasi, air yang mengandung senyawa polutan mengalir melalui celah media dan kontak langsung dengan lapisan massa mikroba (biofilm) (Liao et al., 2014; Said, 2009). Mikroorganisme tumbuh dan berkembang di atas suatu media, dengan membentuk lapisan lendir untuk melekat di atas permukaan media tersebut sehingga membentuk lapisan biofilm (Hadiwidodo, et al., 2012; Liao et al., 2014).

Penggunaan biofilter dalam pengolahan air limbah saat ini banyak dilakukan karena mempunyai nilai manfaat yang tinggi dengan biaya yang relatif murah. Organisasi Kesehatan Dunia atau World Health Organization (WHO) mendorong pengembangan dan penyediaan teknologi 
berbiaya rendah untuk dalam mengolah air limbah rumah tangga (Maeng et al., 2015). Oleh karena itu, di beberapa negara khususnya negara berkembang banyak dimanfaatkan prinsip penggunaan biofilter dalam pengolahan air rumah tangga (Liao et al., 2014).

Media yang dipergunakan sebagai media kontak biofilter, selain efektif sebagai tempat berkembangnya biofilm juga mudah dijumpai di pasaran dan memiliki kelimpahan yang luas. Salah satu alternatif media yang saat ini belum banyak dimanfaatkan sebagai media biofilter yaitu serutan kayu. Pemanfaatan sisa serutan kayu yang dipergunakan sebagai media biofilter perlu diuji keefektifannya sebab kelimpahannya cukup banyak. Rendemen kayu bulat menjadi kayu gergajian masih berkisar antara 50,2\% - 50,4\% (Sopianoor, Yahya, \& Biantary, 2016). Kondisi tersebut mengakibatkan masih adanya sisa kayu yang belum termanfaatkan dan berpotensi menjadi limbah dalam industri kayu olahan.

Tujuan penelitian ini adalah untuk mengetahui efektivitas kontak multimedia dengan penambahan serutan kayu sebagai media biofilter dalam mengolah air limbah domestik rumah tangga (greywater). Dengan penambahan serutan kayu pada media biofilter, diharapkan dapat menjadi alternatif media lokal yang tersedia dalam jumlah banyak dan mampu menekan sisa limbah serutan kayu yang dibuang ke lingkungan. Selain itu, besaran beban pencemar (air limbah sisa domestik rumah tangga) yang masuk ke dalam badan sungai menurun, dan masih berada dibawah daya tampungnya, sesuai dengan baku mutu: P.68/ Menlhk/ Setjen/ Kum.1/ 8/ 2016 tentang baku mutu air limbah domestik. Dengan demikian kualitas hasil air dari suatu Daerah Aliran Sungai akan tetap terjaga sesuai dengan salah satu tujuan pengelolaan DAS, yakni menjaga kualitas air tetap bagus.

\section{BAHAN DAN METODE}

\section{A. Waktu dan Lokasi}

Penelitian ini dilaksanakan pada Bulan Januari sampai dengan Oktober tahun 2018. Lokasi pengambilan bahan penelitian dari Perumahan Villa Bintang Mas yang bertempat di Kelurahan Keranggan, Kecamatan Setu, Kota Tangerang Selatan, Propinsi Banten. Analisis laboratorium dilakukan di Laboratorium Pusat Penelitian dan Pengembangan Kualitas dan Laboratorium Lingkungan, Serpong.

\section{B. Bahan dan Alat}

Penelitian dilakukan dengan mengambil limbah sisa air domestik (grey water). Pengambilan contoh uji air limbah domestik rumah tangga diambil pada Perumahan Villa Bintang Mas, kemudian diuji beberapa parameternya yang mengacu pada Permen LHK Nomor P.68/ Menlhk/ Setjen /Kum.1/ 8/ 2016 tentang Baku Mutu Air Limbah Domestik. Alat yang digunakan dalam penelitian ini adalah Biofilter multimedia (media bioball, honeycomb, zeolite, arang aktif, serta serutan kayu) dengan sistem resirculator. 


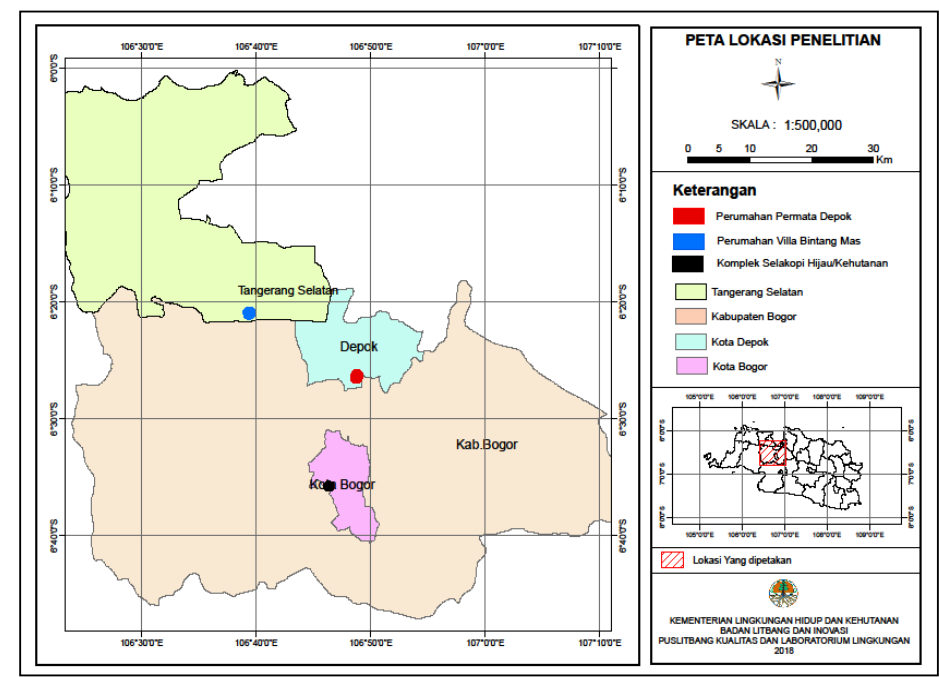

Gambar (Figure) 1. Peta Lokasi Penelitian/ Map of research location Sumber (Source): Analisis data (Data analysis), 2018

\section{Metode Penelitian}

1. Parameter yang diuji meliputi parameter $\mathrm{pH}$, temperatur, BOD, COD, TSS, Minyak lemak, amoniak, dan total Coliform. Contoh uji diambil pada titik outlet gabungan pembuangan limbah domestik rumah tangga secara komunal yang menampung limbah dari keseluruhan perumahan yang dialiri air limbah yang berasal dari aktifitas rumah tangga. Pengambilan contoh dilakukan selama 6 (enam) hari dengan pengulangan sebanyak 1 (satu) kali dan jarak waktu tertentu yang sama pada musim tidak hujan (Oktober 2018), untuk mencegah pengenceran oleh air hujan. Contoh air limbah uji diambil secara komposit (volume sama), dengan menggabungkan air limbah domestik yang diambil.

2. Uji coba biofilter menggunakan multimedia (komposisi media: bioball dan honeycomb $+25 \%$ arang aktif $+25 \%$ Zeolit $+50 \%$ serutan kayu), dilakukan dengan menggunakan contoh uji grey water yang berasal dari kegiatan rumah tangga yang menjadi objek kajian. Biofilter yang digunakan menggunakan sistem resirkulasi, yang bertujuan untuk memperbaiki kualitas air dengan cara melakukan pemutaran air untuk disaring di media biofilter. Proses biofilter adalah reaktor biologis dimana mikroorganisme tumbuh dan berkembang menempel pada permukaan media yang kaku. Media tempat berkembangnya mikroorganisme pada biofilter ini menggunakan media bioball dan honeycomb. Kedua media ini merupakan media buatan yang terbuat dari plastik PVC tempat tumbuh dan berkembangnya bakteri alami pengurai. Aliran air limbah dimasukkan ke dalam reaktor yang di dalamnya diisi dengan media penyangga (media biofilter) dimana mikroorganisme akan tumbuh menempel pada permukaan media (Fuentes, Vizcaino, \& Gonzalez, 2018; Said \& Ruliasih, 2005). Proses ini memerlukan arus yang sesuai sehingga sistem yang digunakan dapat bekerja secara optimal. Sistem yang digerakkan 
mempunyai laju debit air 2 l/detik (Nurhidayat, Nirmala, \& Djokosetyanto, 2012).

3. Analisis sampel uji grey water yang berasal dari kegiatan rumah tangga di lakukan di laboratorium Puslitbang Kualitas dan Laboratorium Lingkungan (P3KLL) sesuai dengan metode yang diterapkan di Laboratorium P3KLL.

4. Efektifitas media dilakukan dengan membandingkan kondisi air limbah sebelum dan sesudah melalui pengolahan biofilter.

\section{Analisis Data}

1. Efisiensi penggunaan biofilter

$\mathrm{E}=\frac{S_{0}-s_{1}}{S_{0}} \times 100$

Keterangan (Remarks) :

$\mathrm{E}=$ Efisiensi alat

$S_{\circ}=$ kadar pencemar sebelum

$\mathrm{S}_{1}=$ kadar pencemar sesudah

2. Laju Pembebanan Oganik

$B_{v}=\frac{Q \times B O D_{i n}}{V}$

Keterangan (Remarks):

$\mathrm{B}_{\mathrm{v}} \quad=$ Laju pembebanan organik ( $\mathrm{kg} \mathrm{BOD} /$ $\mathrm{m}^{3} /$ hari)

$\mathrm{Q}=$ Debit (liter/hari)

$\mathrm{BOD}$ In = Kadar BOD sebelum masuk alat (kg/Liter)

$\mathrm{V} \quad=\quad$ Volume media $\left(\mathrm{m}^{3}\right)$

Kriteria :

Biofilter anaerob $=0,4-4,7 \mathrm{~kg} \mathrm{BOD} / \mathrm{m}^{3} /$ hari.

Biofilter aerob $=0,6-2,1 \mathrm{~kg} \mathrm{BOD} / \mathrm{m}^{3}$ hari.

\section{HASIL DAN PEMBAHASAN}

\section{A. Efisiensi Penggunaan Biofilter} Multimedia

Hasil analisis sampel air limbah yang dilakukan pada 6 sampel limbah domestik dengan 7 parameter yang diuji mengacu pada Permen LHK No.P.68/Menlhk/ Setjen/Kum.1/8/2016 tentang baku mutu air limbah domestik, memperlihatkan bahwa parameter TSS, $\mathrm{NH}_{3}$, dan $\mathrm{pH}$ keseluruhan sampel memenuhi persyaratan baku mutu yang ditentukan. Untuk Parameter BOD, ada tiga sampel memenuhi persyaratan baku mutu yang ditentukan (sampel ke 4, 5, dan 6). Untuk Parameter COD, ada empat sampel yang memenuhi persyaratan baku mutu yang dipersyaratkan. Parameter minyak lemak (ML) hanya satu sampel yang memenuhi persyaratan baku mutu yang ditentukan (sampel ke 5). Walaupun tingkat efisiensi cukup tinggi namum parameter total Coliform tidak ada sampel yang memenuhi baku mutu yang ditetapkan.

1. Tingkat keasaman $(\mathrm{pH})$ dan suhu

Nilai tingkat keasaman $(\mathrm{pH})$ menggambarkan konsentrasi ion hidrogen dan menggambarkan sifat keasaman. Pada air limbah domestik dibandingkan dengan berdasarkan peraturan PerMen LHK No. P.68/2016 (BM) tentang bakumutu air limbah domestik. Batas yang bisa di tolerir sesuai BM adalah pH 6 - 9, hasil pengukuran $\mathrm{pH}$ berada pada range 7,2 8,3 dan masih berada pada range BM yang dipersyaratkan. Air yang bersifat basa dan asam dapat mempengaruhi kehidupan makhluk hidup di perairan. Nilai $\mathrm{pH}$ limbah domestik sebelum dimasukkan ada yang bernilai sekitar 8 dan setelah melewati biofilter $\mathrm{pH}$ menjadi sekitar 7 . Penurunan $\mathrm{pH}$ pada biofilter multimedia efektif dengan adanya penambahan media arang aktif (Fatahilah \& Raharjo, 2007). Suhu 
Tabel (Table) 1. Hasil pengujian air sisa limbah domestik rumah tangga (The result of grey water analysis)

\begin{tabular}{|c|c|c|c|c|c|c|c|c|c|c|c|c|c|c|}
\hline No & & $\begin{array}{l}\text { rameter } \\
\text { dicators) }\end{array}$ & 1 & $\begin{array}{l}\text { Kriteria } \\
\text { (Criteria) }\end{array}$ & 2 & $\begin{array}{l}\text { Kriteria } \\
\text { (Criteria) }\end{array}$ & 3 & $\begin{array}{l}\text { Kriteria } \\
\text { (Criteria) }\end{array}$ & 4 & $\begin{array}{l}\text { Kriteria } \\
\text { (Criteria) }\end{array}$ & 5 & $\begin{array}{l}\text { Kriteria } \\
\text { (Criteria) }\end{array}$ & 6 & $\begin{array}{l}\text { Kriteria } \\
\text { (Criteria) }\end{array}$ \\
\hline \multirow[t]{4}{*}{1.} & \multirow{4}{*}{$\begin{array}{l}\text { BOD (mg/l) } \\
(\mathrm{BM}=30,0)\end{array}$} & Sebelum (Before) & 158,2 & & 142,4 & & 128,9 & & 77,1 & & 96,1 & & 59,5 & \\
\hline & & Sesudah (After) & 93,9 & TMB & 34,7 & TMB & 49,5 & TMB & 29,6 & $\mathrm{MB}$ & 12,9 & $\mathrm{MB}$ & 25,1 & $\mathrm{MB}$ \\
\hline & & $\begin{array}{l}\text { Penurunan } \\
\text { (Reduction) }\end{array}$ & 64,2 & & 107,6 & & 79,4 & & 47,5 & & 83,1 & & 34,4 & \\
\hline & & $\begin{array}{l}\text { \% Efisiensi } \\
\text { (Efficiency) }\end{array}$ & 40,6 & & 75,6 & & 61,6 & & 61,5 & & 86,5 & & 57,9 & \\
\hline \multirow[t]{4}{*}{2.} & \multirow{4}{*}{$\begin{array}{l}\text { COD (mg/l) } \\
(\mathrm{BM}=100,0)\end{array}$} & Sebelum (Before) & 387,0 & & 299,0 & & 321,0 & & 179,0 & & 239,0 & & 122 & \\
\hline & & Sesudah (After) & 140,0 & TMB & 86,8 & $\mathrm{MB}$ & 110,0 & TMB & 63,0 & $\mathrm{MB}$ & 21,0 & $\mathrm{MB}$ & 32,0 & $\mathrm{MB}$ \\
\hline & & $\begin{array}{l}\text { Penurunan } \\
\text { (Reduction) }\end{array}$ & 247,0 & & 212,2 & & 211,0 & & 116,0 & & 218,0 & & 90,0 & \\
\hline & & $\begin{array}{l}\text { \% Efisiensi } \\
\text { (Efficiency) }\end{array}$ & 63,8 & & 70,9 & & 65,7 & & 64,8 & & 91,21 & & 73,8 & \\
\hline \multirow[t]{4}{*}{3.} & \multirow{4}{*}{$\begin{array}{l}\mathrm{ML}(\mathrm{mg} / \mathrm{l}) \\
(\mathrm{BM}=5,0)\end{array}$} & Sebelum (Before) & 66,4 & & 59,7 & & 86,8 & & 20,8 & & 35,6 & & 19,1 & \\
\hline & & Sesudah (After) & 26,2 & TMB & 12,8 & TMB & 15,6 & TMB & 9,7 & TMB & $<2,0$ & $\mathrm{MB}$ & 10,6 & TMB \\
\hline & & $\begin{array}{l}\text { Penurunan } \\
\text { (Reduction) }\end{array}$ & 40,2 & & 46,9 & & 71,2 & & 11,1 & & 32,6 & & 8,5 & \\
\hline & & $\begin{array}{l}\text { \% Efisiensi } \\
\text { (Efficiency) }\end{array}$ & 60,5 & & 78,6 & & 82,0 & & 53,4 & & 91,6 & & 44,5 & \\
\hline \multirow[t]{4}{*}{4.} & \multirow{4}{*}{$\begin{array}{l}\mathrm{pH} \\
(\mathrm{BM}=6-9)\end{array}$} & Sebelum (Before) & 8,3 & & 7,3 & & 8,1 & & 8,1 & & 7,4 & & 7,7 & \\
\hline & & $\begin{array}{l}\text { Sesudah } \\
\text { (After) }\end{array}$ & 7,5 & $M B$ & 7,4 & $\mathrm{MB}$ & 7,3 & $\mathrm{MB}$ & 7,2 & MB & 7,3 & $M B$ & 7,3 & $\mathrm{MB}$ \\
\hline & & $\begin{array}{l}\text { Penurunan } \\
\text { (Reduction) }\end{array}$ & 0,8 & & $-0,02$ & & 0.9 & & 0,8 & & 0,1 & & 0,3 & \\
\hline & & $\begin{array}{l}\text { \% Efisiensi } \\
\text { (Efficiency) }\end{array}$ & 9,5 & & $-0,3$ & & 10,6 & & 10,4 & & 0,8 & & 4,0 & \\
\hline \multirow[t]{3}{*}{5.} & Suhu $\left({ }^{\circ} \mathrm{C}\right)$ & $\begin{array}{l}\text { Sebelum } \\
\text { (Before) }\end{array}$ & 27,5 & & 27,1 & & 27,3 & & 26,4 & & 24,3 & & 27,1 & \\
\hline & & $\begin{array}{l}\text { Sesudah } \\
\text { (After) }\end{array}$ & 29,4 & & 28,2 & & 29,1 & & 29 & & 27 & & 27,2 & \\
\hline & & $\begin{array}{l}\text { Penurunan } \\
\text { (Reduction) }\end{array}$ & $-1,9$ & & $-1,1$ & & $-1,8$ & & $-2,6$ & & $-2,7$ & & $-0,1$ & \\
\hline
\end{tabular}


Vol. 3 No.2, Oktober 2019 : 111-126

\begin{tabular}{|c|c|c|c|c|c|c|c|c|c|c|c|c|c|c|}
\hline No & & $\begin{array}{l}\text { rameter } \\
\text { dicators) }\end{array}$ & 1 & $\begin{array}{l}\text { Kriteria } \\
\text { (Criteria) }\end{array}$ & 2 & $\begin{array}{l}\text { Kriteria } \\
\text { (Criteria) }\end{array}$ & 3 & $\begin{array}{l}\text { Kriteria } \\
\text { (Criteria) }\end{array}$ & 4 & $\begin{array}{l}\text { Kriteria } \\
\text { (Criteria) }\end{array}$ & 5 & $\begin{array}{l}\text { Kriteria } \\
\text { (Criteria) }\end{array}$ & 6 & $\begin{array}{l}\text { Kriteria } \\
\text { (Criteria) }\end{array}$ \\
\hline \multirow[t]{4}{*}{6.} & $\begin{array}{l}\text { TSS (mg/l) } \\
(\mathrm{BM}=30,0)\end{array}$ & $\begin{array}{l}\text { Sebelum } \\
\text { (Before) }\end{array}$ & 94,5 & & 86,3 & & 66,5 & & 34,9 & & 60,5 & & 38,4 & \\
\hline & & $\begin{array}{l}\text { Sesudah } \\
\text { (After) }\end{array}$ & 16,4 & $\mathrm{MB}$ & 5,9 & $\mathrm{MB}$ & 1,6 & $\mathrm{MB}$ & 1,5 & $\mathrm{MB}$ & 1,0 & $\mathrm{MB}$ & 3,9 & $\mathrm{MB}$ \\
\hline & & $\begin{array}{l}\text { Penurunan } \\
\text { (Reduction) }\end{array}$ & 78,1 & & 80,4 & & 64,9 & & 33,4 & & 59,5 & & 34,5 & \\
\hline & & $\begin{array}{l}\text { \% Efisiensi } \\
\text { (Efficiency) }\end{array}$ & 82,6 & & 93,2 & & 97,6 & & 95,7 & & 98,3 & & 89,8 & \\
\hline \multirow[t]{4}{*}{7.} & $\begin{array}{l}\mathrm{NH3}(\mathrm{mg} / \mathrm{l}) \\
(\mathrm{BM}=10,0)\end{array}$ & $\begin{array}{l}\text { Sebelum } \\
\text { (Before) }\end{array}$ & 10,5 & & 17,7 & & 16,4 & & 11,4 & & 14,0 & & 13,1 & \\
\hline & & $\begin{array}{l}\text { Sesudah } \\
\text { (After) }\end{array}$ & 0,2 & $\mathrm{MB}$ & 0,6 & $\mathrm{MB}$ & 0,6 & $\mathrm{MB}$ & 0,96 & $\mathrm{MB}$ & 0,9 & $\mathrm{MB}$ & 0,8 & $\mathrm{MB}$ \\
\hline & & $\begin{array}{l}\text { Penurunan } \\
\text { (Reduction) }\end{array}$ & 10,3 & & 17,1 & & 15,8 & & 10,4 & & 13,1 & & 12,3 & \\
\hline & & $\begin{array}{l}\text { \% Efisiensi } \\
\text { (Efficiency) }\end{array}$ & 97,7 & & 96,8 & & 96,1 & & 91,86 & & 93,6 & & 93,9 & \\
\hline \multirow[t]{4}{*}{8.} & $\begin{array}{l}\text { Coliform } \\
(\mathrm{BM}=3000)\end{array}$ & $\begin{array}{l}\text { Sebelum } \\
\text { (Before) }\end{array}$ & $\begin{array}{r}16 x \\
10^{9}\end{array}$ & & $\begin{array}{r}16 x \\
10^{9}\end{array}$ & & $\begin{array}{r}132 x \\
10^{9}\end{array}$ & & $\begin{array}{r}160 x \\
10^{9}\end{array}$ & & $\begin{array}{r}320 x \\
10^{9}\end{array}$ & & $\begin{array}{r}320 x \\
10^{9}\end{array}$ & \\
\hline & & $\begin{array}{l}\text { Sesudah } \\
\text { (After) }\end{array}$ & $\begin{array}{r}16 x \\
10^{7}\end{array}$ & TMB & $\begin{array}{r}16 x \\
10^{7}\end{array}$ & TMB & $\begin{array}{l}22 x \\
10^{6}\end{array}$ & TMB & $\begin{array}{r}27 x \\
10^{4}\end{array}$ & TMB & $\begin{array}{l}11 x \\
10^{6}\end{array}$ & & $\begin{array}{r}6,3 x \\
10^{6}\end{array}$ & TMB \\
\hline & & $\begin{array}{l}\text { Penurunan } \\
\text { (Reduction) }\end{array}$ & $\begin{array}{r}15,8 \\
\times 10^{9}\end{array}$ & & $\begin{array}{r}15,9 x \\
10^{9}\end{array}$ & & $\begin{array}{r}131,9 \\
\times 10^{9}\end{array}$ & & $\begin{array}{r}159,9 \\
\times 10^{9}\end{array}$ & & $\begin{array}{r}319,9 \\
\times 10^{9}\end{array}$ & & $\begin{array}{r}319,9 \\
\times 10^{9}\end{array}$ & \\
\hline & & $\begin{array}{l}\text { \% Efisiensi } \\
\text { (Efficiency) }\end{array}$ & 99,0 & & 100 & & 100 & & 100 & & 100 & & 100 & \\
\hline
\end{tabular}

Sumber (Source):

Pengolahan data primer (Primary data processing), 2018

Keterangan (Remarks): $\quad$ TMB = Tidak Memenuhi Baku Mutu (not meet the quality standards)

$\mathrm{MB} \quad=$ Memenuhi Baku Mutu (meet the quality standards) 
pada saat pengambilan contoh uji dengan kisaran $24,3-27,5^{\circ} \mathrm{C}$, setelah pengolahan menggunakan biofilter temperatur agak meningkat dengan kisaran $27-29,4^{\circ} \mathrm{C}$. Peningkatan suhu pada biofilter multimedia yang berbahan kaca, sehingga cenderung untuk menyekap panas yang masuk. Nilai yang tidak berbeda jauh juga disampaikan oleh (Nurhidayat et al., 2012), bahwa kinerja biofilter resilkulator berkisar antara $28-31^{\circ} \mathrm{C}$.

\section{Biochemical Oxygen Demand (BOD)}

BOD adalah oksigen yang dibutuhkan untuk mengoksidasikan bahan organik oleh mikroorganisme aerobik sehingga menjadi bentuk anorganik yang stabil. Bahan organik merupakan hasil pembusukan tumbuhan dan hewan yang telah mati atau hasil dari limbah domestik dan industri (Fuentes et al., 2018).

Nilai BOD berbanding lurus dengan jumlah bahan organik di perairan, semakin tinggi jumlah bahan organik di perairan semakin besar pula nilai BOD. Nilai BOD air limbah domestik sebelum diolah berkisar 59 - $158 \mathrm{mg} / \mathrm{l}$, nilai ini melebihi BM yang dipersyaratkan. Dengan pengolahan menggunakan biofilter range BOD menjadi 13 - $94 \mathrm{mg} / \mathrm{l}$, beberapa masih berada di atas baku mutu, pengolahan 1, 2, dan 3 diperoleh nilai BOD yang melebihi $30 \mathrm{mg} / \mathrm{l}$, namun pada pengolahan 4, 5, dan 6 memenuhi BM dengan nilai di bawah 30 $\mathrm{mg} / \mathrm{l}$. Penurunan nilai BOD pada biofilter disebabkan adanya aktifitas penguraian bahan organik pada lapisan biofilm yang terbentuk (Filliazati et al., 2011). Pada Biofilter Multimedia, lapisan biofilm terbentuk setelah dilakukan resikulator dengan air sisa limbah domestik selama

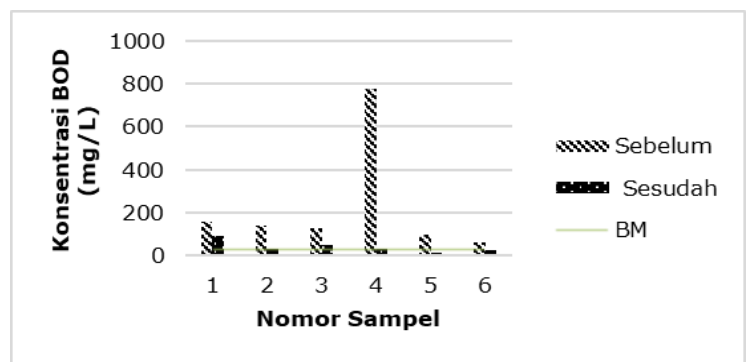

Gambar (Figure) 1. Konsentrasi BOD sebelum dan sesudah ( $B O D$ concentration before and after treatments).

Sumber (Source): $\quad$ Analisis data (Data analysis)

kurang lebih 1-2 minggu. Efisiensi pada pengolahan berkisar 58 - 86\%, pada pengolahan ke 5 di peroleh efisiensi $86 \%$. Hasil tersebut sama dengan penggunaan biofilter anaerob yang menggunakan media kerikil vulkanik yang mencapai $80 \%$ (Sumiyati, Purwanto, \& Sudarno, 2018).

\section{Chemical Oxygen Demand (COD)}

COD merupakan oksigen yang dibutuhkan untuk mengoksidasi zat organik yang ada dalam 1 liter air dengan menggunakan oksidator kalium dikromat. Nilai COD merupakan salah satu indikator parameter pencemar di dalam air yang disebabkan oleh limbah organik, baik yang berasal dari air limbah rumah tangga maupun air limbah industri (Tian et al., 2016). Air limbah rumah tangga dan industri merupakan sumber utama penyebab tingginya nilai COD. Nilai COD pada air limbah yang diambil sebelum pengolahan Biofilter berkisar 122 - 387 $\mathrm{mg} / \mathrm{l}$ dan setelah diolah melalui biofilter, konsentrasi COD nya turun menjadi 21 $140 \mathrm{mg} / \mathrm{l}$. Nilai sesudah pengolahan sebagian mengalami penurunan dan memenuhi persyaratan Baku Mutu (100 $\mathrm{mg} / \mathrm{l})$. Pengolahan ke 4, 5, dan 6 dengan nilai efisiensi 64, 91 dan 74\% menghasilkan 


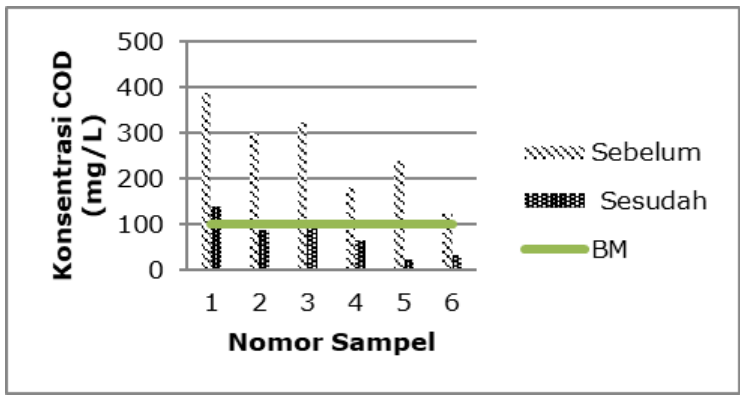

Gambar (Figure) 2. Konsentrasi COD sebelum dan sesudah (COD concentration before and after treatments).

Sumber (Source): $\quad$ Analisis data (Data analysis)

air limbah yang memenuhi BM. Kualitas efluen pada sampel 1 tidak sebaik sampel 2 sampai dengan sampel 6, dan masih berfluktuasi. Hal ini disebabkan karena lapisan biofilm yang terbentuk masih sedikit dan tipis yang menandakan bahwa aktivitas mikroorganisme masih ada dalam tahap adaptasi dan belum tumbuh merata pada seluruh permukaan media, baik pada media bioball maupun serbuk kayu (Amiri, Hartani, \& Zeddouri, 2019; Praptiningtyas et al., n.d.).

\section{Total Suspended Solid (TSS)}

TSS adalah bahan-bahan tersuspensi (diameter $>1 \mu \mathrm{m}$ ) yang bertahan pada saringan milipore dengan diameter pori 0,45 $\mu \mathrm{m}$. Di lingkungan, TSS berasal dari lumpur dan pasir halus serta jasad-jasad renik yang terutama disebabkan oleh kikisan tanah atau erosi tanah yang terbawa ke badan air (Amiri et al., 2019). Dalam limbah rumah tangga, TSS yang tinggi bisa berasal dari berbagai aktivitas seperti mencuci, mandi, dan bersih-bersih rumah. Bertambahnya jumlah TSS dapat meningkatkan nilai kekeruhan yang selanjutnya akan menghambat penetrasi cahaya matahari ke kolam air dan akhirnya

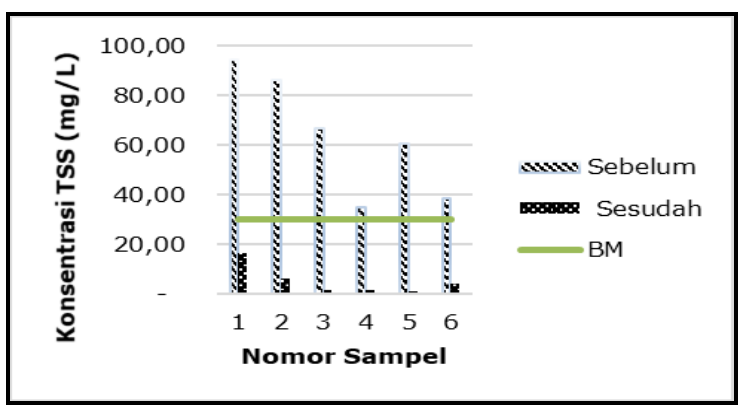

Gambar (Figure) 3. Konsentrasi TSS sebelum dan sesudah (TSS concentration before and after treatments).

Sumber (Source): $\quad$ Analisis data (Data analysis)

berpengaruh terhadap proses fotosintesis di perairan. Dari sampel yang diuji (6 sampel), seluruhnya memenuhi BM yang ditetapkan dalam PerMen LHK No. P.68/2016 sebesar $30 \mathrm{mg} / \mathrm{l}$. Penurunan konsentrasi padatan tersuspensi pada limbah domestik rumah tangga terjadi akibat teradsorpsi di dalam media biofilter. Adsorpsi tersebut dapat terjadi karena adanya interaksi gaya elektrostatik atau Van Der Waals antar molekul (fisisorpsi) maupun oleh adanya interaksi kimia antar molekul (kemisorpsi) (Setyorini, Sarengat, \& Kulit, 2016)

5. Amoniak $\left(\mathrm{NH}_{3}\right)$

Amoniak merupakan salah satu parameter dalam pengukuran baku mutu limbah domestik. Amoniak berasal dari nitrogen organik yang diuraikan oleh organisme heterotrop, yaitu organisme yang membutuhkan nutrientnya dalam bentuk senyawa organik dan memperoleh energi dengan cara mengoksidasi senyawa organik tersebut. Amoniak dalam air permukaan berasal dari air seni, tinja serta penguraian zat organik secara mikrobiologis yang berasal dari air alam atau air buangan industri ataupun limbah 
domestik (Amiri et al., 2019; Herlambang, 2003). Nilai Amoniak yang diukur sebelum pengolahan biofilter berkisar antara 10,5 $\mathrm{mg} / \mathrm{l}$ sampai dengan $17,7 \mathrm{mg} / \mathrm{l}$. Setelah melalui perlakuan biofilter berkisar antara $0,2 \mathrm{mg} / \mathrm{l}$ sampai dengan $0, .9 \mathrm{mg} / \mathrm{l}$. Keseluruhan sampel air yang diambil memenuhi Baku Mutu yang ditetapkan dalam PerMen LHK No. P.68/2016 sebesar $10 \mathrm{mg} / \mathrm{l}$. Penyisihan konsentrasi bahan pencemar terjadi setelah limbah domestik melalui lapisan biofilm yang terbentuk terutama pada media kayu. Sistem biofilm berawal dari terdifusinya perubahan konsentrasi amoniak setelah senyawa polutan dalam hal ini yaitu melalui proses pengolahan ditunjukan amoniak, nitrat dan nitrit (Adisuasono, Wardana, \& Sutrisno, 2014).

6. Minyak lemak

Konsentrasi minyak dan lemak dari (enam) 6 kali pengambilan sampel, hanya sampel ke lima (5) yang berada di bawah

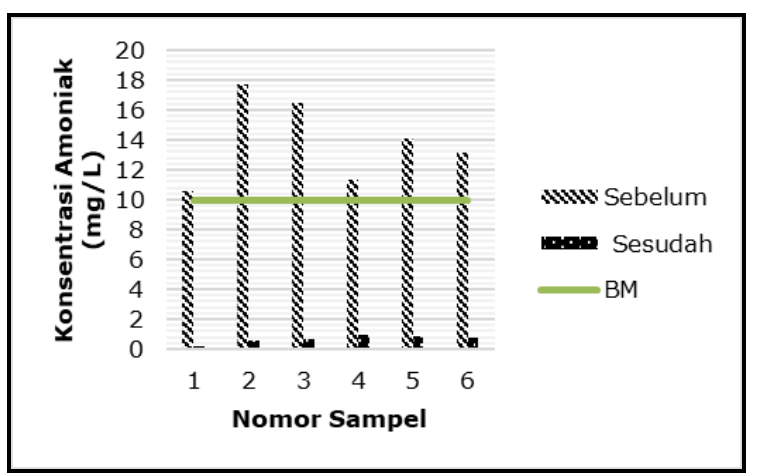

Gambar (Figure) 4. Konsentrasi Amoniak sebelum dan sesudah (Ammoniac concentra-tion before and after treatments).

Sumber (Source): $\quad$ Analisis data (Data analysis) baku mutu yang dipersyaratkan. Untuk 5 (lima) sampel lainnya melebihi BM yang dipersyaratkan. Mengacu pada PerMen LHK No. P.68/2016 tentang baku mutu air limbah domestik, kadar minyak lemak yang diperkenankan sebesar $5 \mathrm{mg} / \mathrm{l}$. Kadar minyak dan lemak di titik sampling yang diambil di lapangan berkisar antara 19,1 $86,8 \mathrm{mg} / \mathrm{l}$. Setelah dilakukan pengolahan melalui biofilter berkisar antara $<2 \mathrm{mg} / \mathrm{l}$ sampai dengan 26,2 mg/l. Pada biofilter multimedia, lapisan minyak terjerap pada lapisan serutan kayu yang berada pada lapisan bawah yang menjadi salah satu media tempat tumbuhnya biofilm, adanya aktifitas mikroorganisme yang tumbuh pada media biofilter mempunyai peran dalam mendegradasi limbah minyak (Filliazati et al., 2011).

Konsentrasi minyak dan lemak tersebut cukup tinggi, menunjukkan pemakaian minyak yang tinggi terutama aktifitas yang berasal dari dapur. Minyak dan lemak yang masuk ke perairan dapat menyebar dan membentuk lapisan tipis yang terdapat di permukaan, emulsi dan fraksi terserap. Bentuk interaksi minyak di perairan sangat kompleks. Nilai konsentrasi ini dipengaruhi oleh nilai grafitasi spesifik, titik didih, tekanan permukaan, viskositas, kelarutan dan penyerapan. Menurut UNESCO/WHO/ UNEP 1992, kadar minyak lemak yang melebihi $0,3 \mathrm{mg} / \mathrm{l}$ bersifat toksik terhadap beberapa jenis ikan tawar (Effendi, Wahyuningsih, \& Wardiatno, 2017). 


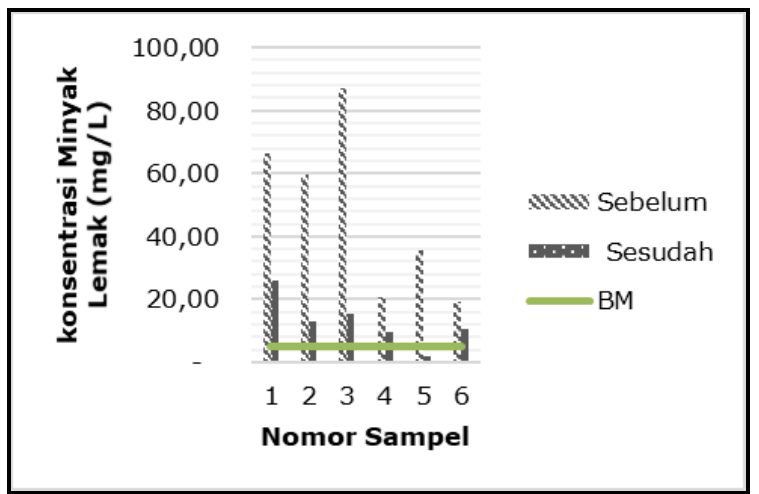

Gambar (Figure) 5. Konsentrasi minyak lemak sebelum dan sesudah (Fat oil concentration before and after treatments).

Sumber (Source): $\quad$ Analisis data (Data analysis)

\section{B. Tingkat Efisiensi Media Biofilter}

Untuk parameter BOD tingkat efisiensi biofilter berkisar dalam rentang 40,6\% sampai dengan $86,5 \%$. Nilai rentang tersebut jauh lebih baik bila dibandingkan dengan penggunaan media tunggal (kayu apu) sebesar 38,5\% (Santoso et al, 2014). Tingkat efisiensi COD berkisar dalam rentang $63,8 \%$ sampai dengan $91,2 \%$. Tingkat penurunan COD dengan menggunakan media zeolite, dan arang batok, dan penambahan sekam Padi hanya menunjukan rentang 30,9 s/d 60,6\% (Dewi \& Buchori, 2016), tingkat efisiensi penurunan $B O D$ dan $C O D$ nilainya tidak berbeda jauh dengan hasil pengolahan yang dilakukan menggunakan media abu vulkanik, untuk BOD $\pm 82,24 \%$ dan COD $\pm 85,68 \%$ (Wardiha \& Prihandono, 2015).

Parameter minyak lemak berkisar dalam rentang 44,5\% sampai dengan $91,6 \%$. Parameter TSS berkisar antara $82,6 \%$ sampai dengan $98,4 \%$. Nilai ini cukup baik apabila dibandingkan dengan biofilter dengan media batu vulkanik yang hanya berkisar 65,8\% (Wardiha \& Prihandono, 2015). Parameter $\mathrm{NH}_{3}$ berkisar dalam rentang $91,9 \%$ sampai dengan $97,7 \%$. Nilai efisiensi yang tinggi pada parameter $\mathrm{NH}_{3}$ menurut Nurhidayat et al., (2012) akibat adanya penambahan media zeolit yang berfungsi menyerap ammonia dalam biofilter. Untuk parameter total Coliform walaupun hasil akhir tidak memenuhi baku mutu yang dipersyaratkan, namun tingkat efisiensi berkisar antara 99,8 s/d 99,9\%.

Efektivitas proses biofilter sangat dipengaruhi oleh jenis serta bentuk media yang digunakan (Chan \& Chang, 2010; Said \& Ruliasih, 2005). Pemilihan media yang efektif untuk pengolahan limbah rumah tangga (greywater) perlu melihat karakteristik influent yang masuk, sehingga tinggat efisiensi biofilter dapat lebih maksimal.

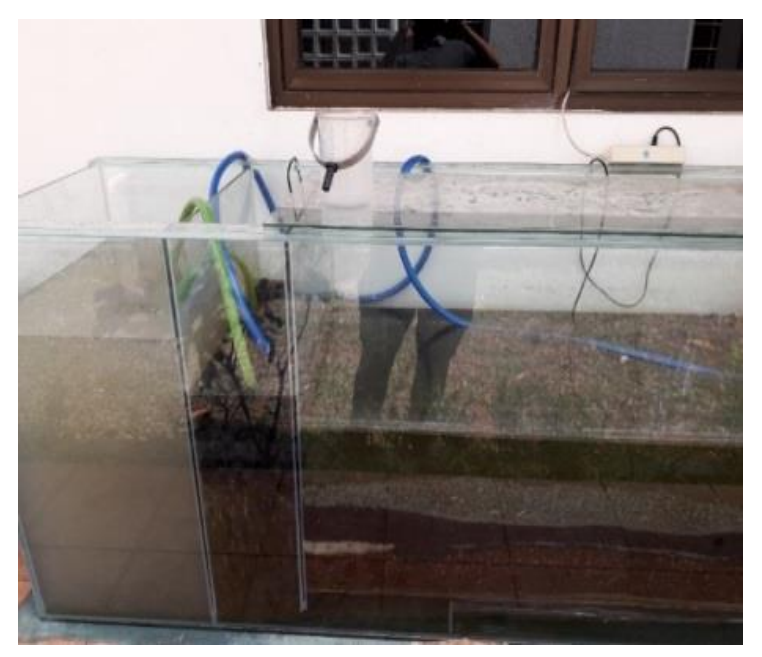

Gambar (Figure) 6. Proses pengolahan air limbah domestik dengan biofilter multimedia (Grey water treatment processes using multimedia bio filter).

Sumber(Source): $\quad$ Foto koleksi pribadi (Personal Photo Collections), 2018 


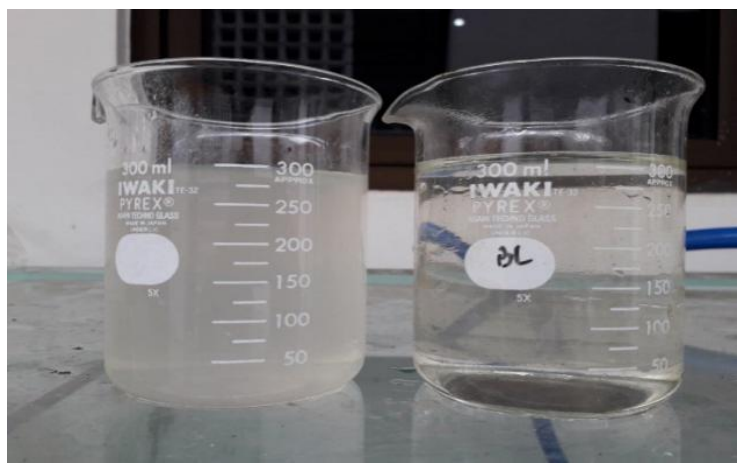

A

B

Gambar(Figure) 7. (A) Grey water sebelum dilakukan pengolahan dengan biofiter multimedia. ((A) Grey water before treatments using multimedia biofilter).

(B) Grey water setelah dilakukan pengolahan dengan biofiter multimedia. ((B) Gray water after treatments using multimedia biofiter).

Sumber (Source): Foto koleksi pribadi (Personal Photo Collections), 2018

\section{Laju Pembebanan Organik}

Laju pembebanan organik didefinisikan sebagai jumlah senyawa organik di dalam air limbah yang dihilangkan atau didegradasi di dalam biofilter per unit volume biofilter per hari (Herlambang, 2001). Kemampuan media Biofilter dalam mendegradasi bahan organik sangat tergantung pada debit aliran, jenis media yang digunakan, serta lama waktu tinggal (Wicaksana, Hastuti, \& Arini, 2015).

Tabel (Table) 1. Laju pembebanan organik (Organic

\begin{tabular}{|c|c|c|c|c|c|}
\hline \multicolumn{6}{|c|}{ loading rate) } \\
\hline \multirow{2}{*}{\multicolumn{6}{|c|}{$\begin{array}{c}\text { Nomor contoh (kg BOD } / \mathrm{m}^{3} / \text { Hari) (Sample } \\
\text { number }\left(\mathrm{kg} \mathrm{BOD} / \mathrm{m}^{3} / \text { day): }\right.\end{array}$}} \\
\hline & & & & & \\
\hline 1 & 2 & 3 & 4 & 5 & 6 \\
\hline 2,4 & 2,2 & 1,9 & 1,2 & 1,5 & 0,9 \\
\hline
\end{tabular}

Sumber (Source): Pengolahan data primer (Primary data processing), 2018
Berdasarkan hasil pengamatan yang dilakukan (Tabel 2), laju pembebanan organik sampel ke 1 sampai dengan sampel ke 6 berkisar antara 0,9 kg BOD $/ \mathrm{m}^{3} /$ hari sampai dengan $2,4 \mathrm{~kg} \mathrm{BOD} / \mathrm{m}^{3} /$ hari, dengan rata-rata Laju pembebanan organik sebesar $1,7 \mathrm{~kg} \mathrm{BOD} / \mathrm{m}^{3} /$ hari. Untuk biofilter dengan waktu tinggal selama 1 hari, nilai efisiensi BOD nya cukup baik (berkisar antara 40,6\% sampai dengan $86,5 \%$ walaupun rata-rata Laju pembebanan organiknya sebesar $1,7 \mathrm{~kg}$ $\mathrm{BOD} / \mathrm{m}^{3} /$ hari. Hasil pengujian yang dilakukan oleh Herlambang (2001), dengan laju pembebanan organik yang berkisar 0,2 $-0,7 \mathrm{~kg} \mathrm{BOD} / \mathrm{m}^{3} /$ hari atau rata-rata $0,4 \mathrm{~kg}$ $\mathrm{BOD} / \mathrm{m}^{3} /$ hari, nilai Efisiensi BOD nya hanya sebesar $53,2 \%$ sampai dengan $65,2 \%$.

\section{IV.KESIMPULAN}

Penggunaan multimedia biofilter dengan penambahan serutan kayu efektif dalam penyisihan pencemar pada air limbah domestik rumah tangga. Hasil pengujian air limbah domestik rumah tangga pada biofilter dengan multimedia yang menggunakan serutan kayu, untuk keseluruhan parameter mengalami tingkat efisiensi minimal sebesar 40,6\% (parameter BOD) sampai dengan $100 \%$ (parameter total Coliform). Laju pembebanan organik berkisar antara 0,9 $\mathrm{kg} \mathrm{BOD} / \mathrm{m}^{3} /$ hari sampai dengan $2,4 \mathrm{~kg}$ $\mathrm{BOD} / \mathrm{m}^{3} /$ hari, dengan rata-rata sebesar 1,7 $\mathrm{kg} \mathrm{BOD} / \mathrm{m}^{3} /$ hari. Penelitian ini menunjukkan parameter total Coliform yang tidak memenuhi standar baku mutu yang dipersyaratkan dalam PerMenLHK No.P.68/ Menlhk/ Setjen/ Kum.1/ 8/ 2016 untuk seluruh pengujian sampel yang 
dilakukan, sehingga selanjutnya masih perlu dilakukan penelitian penambahan disinfektan guna menurunkan kadar Coliform.

\section{UCAPAN TERIMA KASIH}

Penulis mengucapkan terimakasih kepada seluruh tim Penelitian Penentuan Pola Konsumsi Air dan Efisiensi Pemanfaatan Air limbah Rumah Tangga (Greywater) dengan Pemanfaatan IPTEK Sederhana Tahun 2018, Tim Laboratorium Air P3KLL yang telah membantu dalam analisis dan pengujian sampel, Manajemen Puslitbang Kualitas dan Laboratorium Lingkungan, Pemerintah Kelurahan Keranggan, Kecamatan Setu yang membantu dalam kelancaran pelaksanaan pengambilan sampel di lapangan, serta kepada para pihak yang ikut mendukung dalam penulisan dan penyusunan jurnal ini.

\section{DAFTAR PUSTAKA}

Adisuasono, R. T., Wardana, I. W., \& Sutrisno, E. (2014). Penurunan konsentrasi amoniak dalam limbah cair domestik dengan teknologi kolam (pond)-biofilm menggunakan media biofilter pipa PVC sarang tawon dan bata ringan. Teknik Lingkungan, 3(4), 1-12.

Amiri, K., Hartani, T., \& Zeddouri, A. (2019). The assessment of an integrated biofilter systems for the wastewaters treatment in arid regions (Touggourt, Algeria). Management of Environmental Quality: An International Journal. https://doi.org/10.1108/MEQ-052018-0095
Badan Pusat Statistik Indonesia. (2013). Indonesia Population Projection 20102035. Badan Pusat Statistik Indonesia. Jakarta: Badan Pusat Statistik. https://doi.org/2101018

Chan, W.-C., \& Chang, S.-C. (2010). Synthesis of a new type Poly (vinyl alcohol)/Peat/Bamboo

Charcoal/KNO3 composite bead used as biofilter material. Journal of Applied Polymer Science, 116(5), 2658-2667.

https://doi.org/10.1002/app

Dewi, Y. S., \& Buchori, Y. (2016). Penurunan COD, TSS pada penyaringan air limbah tahu menggunakan media kombinasi pasir kuarsa, karbon aktif, sekam padi dan zeolit. Jurnal Ilmiah Satya Negara Indonesia, 9(1), 74-80.

DJ Bayu. (2018). Pengembangan perumahan tumbuh pesat di Jakarta dan 34 Kota Satelit.

Effendi, H., Wahyuningsih, S., \& Wardiatno, Y. (2017). The use of nile tilapia (Oreochromis niloticus) cultivation wastewater for the production of romaine lettuce (Lactuca sativa L. var. longifolia) in water recirculation system. Applied Water Science, 7(6), 3055-3063. https://doi.org/10.1007/s13201-0160418-z

Fatahilah, \& Raharjo, I. (2007). Penggunaan karbon aktif dan zeolit sebagai komponen adsorben saringan pasir cepat (sebuah aplikasi teknologi sederhana dalam proses penjernihan air bersih). Jurnal Zeolit Indonesia, 6(2), 43-46.

Filliazati, M., Apriani, I., \& Zahara, T. A. (2011). Pengolahan limbah cair 
domestik dengan biofilter aerob menggunakan media bioball dan tanaman kiambang. Teknik Lingkungan, 1-10.

Fuentes, N., Vizcaino, L. Y., \& Gonzalez, H. E. (2018). Integrated system "biodigester - biofilter": a sustainable option for the environmental management of wastewater from small communities. Contemporary Engineering Sciences, 11(87), 43294337.

https://doi.org/10.12988/ces.2018.88 446

Hadiwidodo, M., Oktiawan, W., Primadani, A. R., Bernadette Nusye Parasmita, \& Gunawan, I. (2012). Pengolahan air lindi dengan proses kombinasi biofilter anaerob-aerob dan wetland. Jurnal Presipitasi, 9(2), 84-95.

Herlambang, A. (2001). Pengaruh pemakaian biofilter struktur sarang tawon pada pengolah limbah organik sistem kombinasi anaerob-aerob. Teknologi Lingkungan, 2(1), 28-36.

Herlambang, A. (2003). Proses denitrifikasi dengan sistem biofilter untuk pengolahan air limbah yang mengandung nitrat. Teknik Lingkungan, 4(1), 46-55.

Jing, Z., He, R., Hu, Y., Niu, Q., Cao, S., \& Li, Y. Y. (2015). Practice of integrated system of biofilter and constructed wetland in highly polluted surface water treatment. Ecological Engineering, 75, 462-469. https://doi.org/10.1016/j.ecoleng.201 4.12.015

Liao, X., Chen, C., Zhang, J., Dai, Y., Zhang, X., \& Xie, S. (2014). Operational performance, biomass and microbial community structure: Impacts of backwashing on drinking water biofilter. Environmental Science and Pollution Research, 22(1), 546-554. https://doi.org/10.1007/s11356-0143393-7

Maeng, M., Choi, E., \& Dockko, S. (2015). Reduction of organic matter in drinking water using a hybrid system combined with a rock biofilter and membrane in developing countries. International Biodeterioration and Biodegradation, 102, 223-230. https://doi.org/10.1016/j.ibiod.2015. 02.005

Nurhidayat, Nirmala, K., \& Djokosetyanto, D. (2012). Efektivitas kinerja media biofilter dalam sistem resirkulasi terhadap kualitas air untuk pertumbuhan. Akuakultur, 7(2), 279292.

Praptiningtyas, I., Iqbal, R., Soewondo, P., Teknik, F., Bandung, I. T., \& Bandung, J. G. (n.d.). Efektivitas Penggunaan Serbuk Kayu sebagai Media Biofilter dalam Pengolahan Air Limbah Domestik The Effectivity of Sawdust as A Biofilter Media in Domestic Wastewater Treatment Program Studi Teknik Lingkungan, tumbuh yang lebih baik bagi mikroorganisme s, 110.

Said, N. I. (2009). Uji kinerja pengolahan air siap minum dengan proses biofiltrasi, ultrafiltrasi dan reverse osmosis (RO) dengan air baku air sungai. JAI, 5(2), 144-161.

Said, N. I., \& Ruliasih. (2005). Tinjauan aspek teknis pemilihan media biofilter untuk pengolahan air limbah. JAI, 1(3).

Santoso, U., Mahreda, E. S., Shadiq, F., \& Biyatmiko, D. (2014). Pengolahan 
limbah cair sasirangan melalui kombinasi metode filtrasi dan fitoremidiasi sistem lahan basah buatan menggunakan tumbuhan air yang berbeda. EnviroScience, 10, 157170.

Setyorini, I., Sarengat, N., \& Kulit, B. B. (2016). Pengolahan Limbah Cair Industri lateks Pekat dengan Berbagai Adsorben Lokal. In Prosiding Seminar Nasional Kulit, Karet dan Plastik Ke-5 (pp. 207-216).

Sopianoor, Yahya, Z., \& Biantary, M. P. (2016). Studi rendemen bahan baku log pada IU-IPHHK Rusmandiansnyah di Kecamatan Damai Kabupaten Kutai Barat. Agrifor, XV(Oktober), 289-296.

Sumiyati, S., Purwanto, P., \& Sudarno, S. (2018). Decreasing of BOD concentration on artificial domestic wastewater using anaerob biofilter reactor technology. E3S Web of Conferences, 31, 03016. https://doi.org/10.1051/e3sconf/201 83103016

Tian, Q., Ong, S. K., Xie, X., Li, F., Zhu, Y., Wang, F. R., \& Yang, B. (2016). Enhanced phosphorus recovery and biofilm microbial community changes in an alternating anaerobic/aerobic biofilter. Chemosphere, 144, 17971806.

https://doi.org/10.1016/j.chemosphe re.2015.10.072

Wardiha, M. W., \& Prihandono, A. (2015). Efektifitas biofilter dengan media kontak batu vulkanik untuk mengolah efluen air limbah domestik pada tangki septik konvensional. Bumi Lestari, 15(Agustus), 125-135.

Wicaksana, S. N., Hastuti, S., \& Arini, E. (2015). Performa produksi ikan Lele Dumbo (Clarias gariepinus) yang dipelihara dengan sistem biofilter akuaponik dan konvensional. Journal of Aquaculture Management and Technology, 4(4), 109-116. 


\section{Halaman ini sengaja dikosongkan}

